\title{
Jurist-Diction
}

Volume 4 No. 2, Maret 202

\section{Model Pemilihan Umum Serentak Nasional Pasca Pelaksanaan Pemilihan Umum 2019}

\author{
Octara Steni Paendong \\ tarasteni@yahoo.com \\ Universitas Airlangga
}

\begin{abstract}
How to cite:
Octara Steni Paendong, 'Model Pemilihan Umum Serentak Nasional Pasca Pelaksanaan Pemilihan Umum 2019' (2021) Vol. 4 No. 2 Jurist-Diction.

Histori artikel:

Submit 9 Januari 2021;

Diterima 18 Februari 2021;

Diterbitkan 1 Maret 2021.

DOI:

10.20473/jd.v4i2.25786

p-ISSN: 2721-8392

e-ISSN: 2655-8297
\end{abstract}

\section{Abstract}

This article titled "Judicial Review Of Simultaneous Of Election After General Election 2019". Its using normative writing method and also use statute approach, conceptual approach, and case approach. Writer on this research want to give alternative optional for implementation of simultaneous general election in the future. From legal research can be concluded type of election which can be alternative for the next election is simultaneous general election which can be differentiated in local level although national level. The second main problem is about the alternative model implementation of the Simultaneous General Election, the alternative model for the next Simultaneous General Election is by separating between the implementation of Simultaneous General Elections into two levels which is at the local level and national level. Simultaneous General Election at Local level purpose to elect the Governor, Regent/Mayor, Provincial Regional House of Representatives, and District/City Regional House of Representatives at one time. General Elections at The National Level purpose to elect President, House of Representatives and Regional Representative Board at one time. With difference implementation time for 24 until 30 month between simultaneous general election at the national level and simultaneous general election at the local level.

Keywords: Simultaneus General Election; General Election 2019; Alternative Model of The Simultaneous General Election.

\begin{abstract}
Abstrak
Artikel ini berjudul "Model Pemilihan Umum Serentak Nasional Pasca Pelaksanaan Pemilihan Umum 2019", metode penulisan yang digunakan bersifat normatif, dengan menggunakan pendekatan undang-undang, pendekatan konseptual, serta pendekatan kasus. Tujuan dari penulisan ini adalah untuk memberikan model Pemilihan Umum alternatif pada Pemilihan Umum serentak nasional yang akan datang. Dari penelitian hukum yang telah dilakukan dapat disimpulkan model Pemilihan Umum serentak yang dapat menjadi alternatif untuk Pemilihan Umum serentak selanjutnya adalah Pemilihan Umum serentak yang membedakan penyelenggaraan Pemilihan Umum serentak di tingkat lokal untuk memilih memilih Gubernur, Bupati/Walikota, DPRD Provinsi, dan DPRD Kabupaten/Kota dan Pemilihan Umum di tingkat nasional untuk memilih memilih Presiden, DPR, dan DPD dengan disertai jeda waktu selama 24-30 bulan antara Pemilihan Umum di tingkat nasional dan Pemilihan Umum di tingkat lokal.

Kata Kunci: Pemilihan Umum Serentak; Pemilihan Umum 2019; Model Pemilihan Umum Alternatif.
\end{abstract}

Copyright (C) 2021 Universitas Airlangga 


\section{Pendahuluan}

Dalam sejarah pelaksanaan Pemilihan Umum di Indonesia Pemilihan Umum 2019 dilaksanakan secara berbeda karena untuk pertama kalinya Pemilihan Umum di Indonesia dilaksanakan secara serentak nasional. Pemilihan Umum serentak nasional 2019 dilaksanakan untuk memilih presiden dan wakil presiden, memilih anggota DPR ,DPD, DPRD Provinsi, dan DPRD Kabupaten/Kota. Pelaksanaan Pemilihan Umum serentak 2019 merupakan konsekuensi dari Putusan Mahkamah Konstitusi Nomor 14/PUU-11/2013 tentang Pemilihan Umum serentak. Putusan tersebut dikeluarkan setelah Mahkamah Konstitusi mengabulkan dan mengeluarkan putusan uji materiil (judicial review) dari gugatan yang diajukan pada tahun 2013 oleh Effendi Gazali dan Koalisi Masyarakat untuk Pemilihan Umum serentak. Putusan yang dikeluarkan oleh Mahkamah Konstitusi No. 14/PUU-11/2013 merupakan pengujian Pasal 3 ayat (5), Pasal 12 ayat (1) dan ayat (2), Pasal 14 ayat (2), dan Pasal 112 Undang-Undang No.42 Tahun 2008 tentang Pemilihan Umum Presiden dan Wakil Presiden. Beberapa pasal yang diujikan mengatur ketentuan Pemilihan Umum Anggota Lembaga Perwakilan dan Pemilihan Umum Presiden dan Wakil Presiden yang dilaksanakan secara terpisah.

Berdasarkan ketentuan Pasal 167 ayat (3) Undang-Undang Nomor 7 Tahun 2017 tentang Pemilihan Umum, pemungutan suara dilaksanakan secara serentak pada hari libur atau hari yang diliburkan secara nasional. Terdapat fakta bahwa pada Pemilihan Umum tahun 2019 pelaksanaan Pemilihan Umum Presiden dan Wakil Presiden, Pemilihan DPR, DPRD Provinsi, dan DPRD Kabupaten/Kota yang dilaksanakan secara bersamaan dalam satu waktu, dapat dikatakan bahwa sistem Pemilihan Umum serentak ini memiliki beberapa kelemahan, antara lain:

a. Kelemahan yang pertama dialami oleh masyarakat sebagai pemilih, yaitu terdapat ketidak praktisan dan kurang efisien karena banyaknya surat suara yang harus dicoblos oleh pemilih yang terdiri dari surat suara untuk memilih presiden dan wakil presiden, surat suara untuk memilih DPD, surat suara untuk memilih DPR, surat suara untuk memilih DPRD Provinsi, dan surat suara untuk memilih DPRD Kabupaten/Kota yang seluruhnya berjumlah 5 (lima) kertas 
suara harus di coblos dalam waktu yang bersamaan. Hal tersebut tentu dapat menimbulkan kebingungan di masyarakat yang memiliki hak sebagai pemilih dalam pelaksanaan Pemilihan Umum serentak.

b. Kelemahan yang kedua dialami oleh penyelenggara Pemilihan Umum karena selama pelaksanaan Pemilihan Umum Serentak 2019 terdapat 527 orang meninggal dunia dan 11.239 orang sakit diakibatkan oleh penyelenggaraan Pemilihan Umum serentak. Korban jiwa tersebut seluruhnya merupakan petugas penyelenggara dan pengawas Pemilihan Umum. Berikut ini adalah data jumlah petugas Pemilihan Umum yang meninggal berdasarkan laporan dari dinas kesehatan setiap provinsi yang disampaikan dalam bentuk tabulasi: ${ }^{1}$

Tabel 1. Laporan Jumlah Petugas Penyelenggara Pemilihan Umum Yang Meninggal Selama Pelaksanaan Pemilihan Umum 2019 Di Indonesia

\begin{tabular}{lll}
\hline No. & Provinsi & Jumlah Korban Meninggal Dunia \\
\hline 1. & Sumatera Utara & 9 jiwa \\
\hline 2. & Sulawesi Selatan & 4 jiwa \\
\hline 3. & Bangka Belitung & 1 jiwa \\
\hline 4. & Sulawesi Barat & 1 jiwa \\
\hline 5. & Jawa Barat & 177 jiwa \\
\hline 6. & Jawa Timur & 82 jiwa \\
\hline 7. & Jawa Tengah & 44 jiwa \\
\hline 8. & Sumatera Barat & 1 jiwa \\
\hline 9. & Bengkulu & 7 jiwa \\
\hline 10 & Kepulauan Riau & 4 jiwa \\
\hline 11. & Lampung & 23 jiwa \\
\hline 12. & Sumatera Selatan & 25 jiwa \\
\hline 13. & Jambi & 6 jiwa \\
\hline 14. & Riau & 7 jiwa \\
\hline 15. & Banten & 29 jiwa \\
\hline 16. & DKI Jakarta & 18 jiwa \\
\hline 17. & Yogyakarta & 10 jiwa \\
\hline 18. & Kalimantan Tengah & 6 jiwa \\
\hline 19. & Kalimantan Timur & 6 jiwa \\
\hline 20. & Kalimantan Selatan & 8 jiwa \\
\hline 21. & Kalimantan Barat & 26 jiwa \\
\hline
\end{tabular}

${ }^{1}$ Sandro Gatra, 'Data Kemenkes: 527 Petugas KPPS Meninggal, 11.239 Orang Sakit', Kompas News, 2019, https://nasional.kompas.com/read/2019/05/16/17073701/data-kemenkes-527petugas-kpps-meninggal-11239-orang-sakit?page=all, diakses pada tanggal 22 Okotober 2019. 


\begin{tabular}{lll}
\hline 22. & Gorontalo & 0 jiwa \\
\hline 23. & Bali & 2 jiwa \\
\hline 24. & NTB & 7 jiwa \\
\hline 25. & Sulawesi Utara & 2 jiwa \\
\hline 26. & Sulawesi Tenggara & 6 jiwa \\
27. & Maluku Utara & 0 jiwa \\
\hline 28. & Maluku & 1 jiwa \\
\hline
\end{tabular}

Petugas KPPS rentan mengalami kelelahan sebab jam kerja mereka yang tidak menentu. Petugas KPPS memiliki tugas untuk mendata sekian ratus orang dan juga bertugas menjaga kotak suara ketika pemilihan telah selesai dilakukan, walaupun kelelahan bukan menjadi faktor pemicu kematian mendadak. Akan tetapi menurut ahli hematologi dari Universitas Indonesia, Zubairi Djoerban menuturkan kelelahan bisa menjadi faktor pemicu penyakit stroke dan jantung. Menurut Zubairi, bekerja berlebihan bisa menyebabkan jantung tidak kuat atau menjadi pemicu stroke. Apalagi jika ada riwayat darah tinggi, diabetes, merokok dan bekerja berhari-hari, bisa saja meninggal mendadak. ${ }^{2}$ Dikaitkan dengan Pemilihan Umum serentak 2019, maka banyaknya calon legislatif akibat dari sistem tersebut dapat menjadi salah satu alasan ditambah lagi kertas suara yang berjumlah lima. Seperti dalam proses pelaksanaan rekapitulasi suara yang cenderung menjadi rumit dan membutuhkan waktu yang lebih banyak karena banyaknya nama calon legislatif yang berada di kertas suara. Sehingga tenaga dan stamina yang dibutuhkan oleh para petugas penyelenggara dan pengawas Pemilihan Umum juga lebih banyak.

c. Kelemahan yang terakhir dialami oleh calon legislatif dan partai politik. Para calon legislatif akan berjuang dua kali yaitu berjuang untuk partai dan berjuang untuk dirinya sendiri. Demikian juga dengan Partai Politik, maka tidak dipungkiri juga akan membuka peluang praktik-praktik kecurangan salah satunya adalah money politik. Para calon legislatif akan saling bersaing dalam satu partai politiknya untuk mendapatkan suara dan mendapatkan kursi di parlemen.

\footnotetext{
${ }^{2}$ Khadijah Nur Azizah, 'Kelelahan Dan Kaitannya Dengan Kematian Mendadak Petugas KPPS', Detik News, 2019, https://health.detik.com/berita-detikhealth/d-4548216/kelelahan-dankaitannya-dengan-kematian-mendadak-petugas-kpps. diakses pada tanggal 13 Agustus 2019.
} 
Selain calon legislatif yang akan bersaing demi memperoleh kursi. Para partai politik juga akan bersaing guna memenuhi target ambang batas parlemen atau parliamentary threshold sebesar 4\% (empat persen).

Beranjak dari pemikiran diatas, serta ditambah dengan fakta yang terjadi dalam Pemilihan Umum serentak nasional 2019 yang menggunakan sistem proposional terbuka dalam Pemilihan Umum Legislatif. Sistem proposional terbuka dirasa perlu dikaji kembali dalam Pemilihan Umum selanjutnya yaitu Pemillihan Umum 2024.

\section{Varian Pemilihan Umum Serentak}

Negara Indonesia secara umum dengan berdasarkan pada varian secara empiris dan hipotesis menurut Syamsuddin Haris,dkk.. terdapat setidaknya enam model Pemilihan Umum serentak sebagai berikut:

Model pertama, yaitu Pemilihan Umum serentak yang dilaksanakan sekaligus yaitu dilaksanakan untuk pemilihan semua posisi publik di tingkat nasional sampai dengan kabupaten/kota, Pemilihan Umum sekaligus tersebut dilaksanakan satu kali dalam lima tahun. Pemilihan Umum serentak yang dilaksanakan secara sekaligus tersebut diselenggarakan untuk memilih anggota legislatif yang terdiri dari DPR, DPD, DPRD Provinsi, serta DPRD Kabupaten/Kota, memilih calon presiden serta wakil presiden, dan memilih kepala daerah. Oleh karena penyelenggaraannya digunakan untuk memilih semua jabatan publik secara sekaligus, maka Pemilihan Umum ini biasa disebut juga dengan pemilihan tujuh kotak atau "Pemilihan Umum borongan". ${ }^{3}$ Dalam pemilihan model pertama tersebut yang diselenggarakan sekaligus untuk semua jabatan memiliki kelemahan antara lain, yaitu: (1) Pemilih akan membutuhkan waktu yang lebih lama didalam bilik karena banyaknya jumlah surat suara yang akan dipilih oleh pemilih dan dengan banyaknya jumlah surat suara yang akan dipilih akan menyebabkan pemilih kesulitan untuk mengetahui dan memilih para calon pejabat politik, eksekutif serta legislatif yang akan dipilih karena begitu banyaknya nama calon yang ditampilkan; (2) Karena terdapat banyak calon

\footnotetext{
${ }^{3}$ Syamsuddin Haris, Pemilihan Umum Nasional Serentak 2019 ( Pustaka Belajar 2016).[20-21].
} 
yang akan dipilih, maka bentuk kertas suara akan cenderung tebal dan/ atau lebar sehingga pemilih juga akan kesulitan menggunakan kertas suaranya; (3) Pemilihan yang dilakukan secara serentak dan sekaligus untuk memilih semua jabatan legislatif dan eksekutif akan membuat persiapan logistik menjadi rumit karena pelaksanaan Pemilihan Umum serentak tersebut dilaksanakan dari tingkat nasional, regional dan lokal; (4) Dengan banyaknya calon yang akan dipilih, maka proses rekapitulasi suara akan menjadi rumit serta membutuhkan waktu yang cukup lam bisa sampai lebih dari dua minggu. ${ }^{4}$ Kelebihan dalam Pemilihan Umum serentak model pertama adalah anggaran yang akan dikeluarkan negara untuk pelaksanaan Pemilihan Umum tidak akan terlalu banyak karena pelaksanaan Pemilihan Umum untuk memilih caloncalon yang akan menduduki semua posisi publik dilaksanakan secara serentak satu kali dalam lima tahun jadi tujuan negara untuk dapat lebih menghemat anggarannya dalam pelaksanaan Pemilihan Umum dapat dilakukan. Selain itu, keadaan negara akan lebih stabil dari tingkat kabupaten/kota sampai dengan tingkat nasional karena suasana tegang yang terjadi antar pendukung calon tidak terjadi berkelanjutan karena tidak ada jarak antara pelaksanaan Pemilihan Umum ditingkat kabupaten/kota dan pelaksanaan Pemilihan Umum tingkat nasional.

Kedua, Pemilihan Umum serentak yang diselenggarakan untuk memilih seluruh jabatan legislatif di tingkat pusat maupun daerah yang selanjutnya dilanjutkan dengan Pemilihan Umum serentak untuk memilih jabatan eksekutif baik di tingkat pusat maupun daerah. Model Pemilihan Umum tersebut dikenal dengan clustered concurrent election yaitu Pemilihan Umum untuk memilih anggota legislatif seperti DPR, DPD, DPRD Provinsi dan DPRD Kabupaten/Kota yang diselenggarakan seperti selama ini dilakukan berbarengan sesuai dengan waktu yang telah ditentukan yang selanjutnya dilanjutkan dengan Pemilihan Umum Presiden dan Wakil Presiden, Gubernur dan Bupati/walikota dalam beberapa bulan kemudian. ${ }^{5}$ Dalam model kedua Pemilihan Umum serentak tersebut, kekuatannya terletak pada para pemilih dapat mengerti adanya diferensiasi Pemilihan Umum eksekutif dengan Pemilihan Umum

\footnotetext{
$4 \quad$ ibid.[24].

${ }^{5}$ ibid.[21].
} 
legislatif dengan sangat baik. Namun, terdapat juga kelemahan dalam model kedua Pemilihan Umum serentak tersebut yaitu: (1) para pemilih akan mengalami kesulitan dalam memilah para calon anggota legislatif dari banyaknya tingkatan tersebut yang terdiri dari nasional, provinsi dan kabupaten/kota; (2) sama dengan kelemahan dalam model Pemilihan Umum pertama, terdapat kerumitan dalam penyiapan dan pengiriman logistik; (3) tidak jauh berbeda juga kelemahan yang ada dalam model pemilihan kedua dengan model pemilihan pertama yaitu masalah terkait kertas suara yang akan sangat tebal dan/ atau lebar yang akan memberikan kesulitan terhadap para pemilih; (4) selain masalah kertas suara dan pengiriman logistik yang merupakan kelemahan dari model pemilihan serentak pertama, dalam model pemilihan serentak yang kedua juga mempunyai kelemahan dalam perhitungan suara yang akan cenderung lebih rumit dan membutuhkan waktu yang cukup lama. Dengan dilaksanakannya secara terpisah Pemilihan Umum legislatif dan eksekutif maka pejabat eksekutif yang terpilih pada tingkat nasional sampai dengan regional memungkinkan untuk tidak mendapat dukungan dari koalisi partai mayoritas di parlemen karena dengan pemisahan Pemilihan Umum tersebut menyebabkan tidak terdapat kaitan politik antara hasil Pemilihan Umum legislatif dengan Pemilihan Umum eksekutif. ${ }^{6}$ Kelebihan dalam model Pemilihan Umum serentak kedua juga tidak jauh berbeda dengan pelaksanaan Pemilihan Umum serentak dengan model pertama yaitu tujuan negara untuk lebih menghemat biaya dalam pelaksanaan Pemilihan Umum dapat terwujud.

Ketiga, dalam model ini pelaksanaan Pemilihan Umum serentak dilaksanakan secara terpisah dengan diberikan masa jeda waktu antara Pemilihan Umum nasional dengan Pemilihan Umum lokal yaitu 2,5 tahun (model concurrent election with mid-term elections). Dalam model ini Pemilihan Umum presiden, DPR, dan DPD diselenggarakan secara serentak lalu dua atau tiga tahun kemudian dilanjutkan dengan penyelenggaraan Pemilihan Umum serentak untuk pemilihan gubernur, bupati/walikota, DPRD Provinsi, dan DPRD Kabupaten/Kota. Penyelenggaraan Pemilihan Umum serentak dengan menggunakan model ketiga ini akan menimbulkan

${ }^{6}$ ibid. [25]. 
suatu hubungan eksekutif nasional dan lokal dengan baik dan juga dengan model ini akan menghasilkan suatu kekuatan yang berkaitan dengan hasil antara pemilihan eksekutif dan legislatif dengan diiringi juga adanya keselarasan hubungan antara eksekutif pada tingkatan pusat dan daerah. ${ }^{7}$ Dengan menggunakan model pemilihan ini akan ada kelebihan yang dirasakan oleh pemilih yaitu pemilih akan lebih rasional dalam menentukan pilihannya dan juga beban dan volume pekerjaan penyelenggara Pemilihan Umum dapat terkurangi. Namun, dalam sistem ini juga masih terdapat kelemahan jika digunakan yaitu dibutuhkannya waktu penyesuaian karena terjadi peralihan pemilihan DPRD yang selama ini dilaksanakan bersamaan dengan Pemilihan Umum legislatif untuk memilih DPR serta DPRD menjadi Pemilihan Umum daerah.

Keempat, dalam model ini penyelenggaraan Pemilihan Umum serentak akan dibedakan waktunya secara interval antara Pemilihan Umum serentak di tingkat nasional serta Pemilihan Umum serentak di tingkat lokal (model concurrent election with regional-based concurrent elections). Sehingga penyelenggaran Pemilihan Umum Presiden dan Wakil Presiden serta pemilihan legislatif untuk DPR dan DPD diselenggarakan secara serentak bersamaan yang kemudian dilanjutkan dengan penyelenggaran Pemilihan Umum serentak di tingkat lokal untuk memilih DPRD Provinsi dan DPRD Kabupaten/Kota serta Pemilihan Umum serentak gubernur dan bupati/walikota dengan didasarkan pada pengelompokan region yang penyelengggarannya pada tahun kedua jadi dari satu wilayah ke wilayah yang lain terdapat jeda waktu satu tahun. Dilaksanakannya model ini memiliki kelemahan yaitu penyelenggaraan Pemilihan Umum serentak akan tetap melahirkan banyaknya Pemilihan Umum di Indonesia di tingkat lokal yang akan menjadi rumit. Akan tetapi, dengan menggunakan model Pemilihan Umum serentak tersebut juga memiliki kelebihan yaitu pemilih akan dapat melakukan evaluasi setiap tahun terhadap pemerintah dan partai politik sehingga partai politik akan lebih giat bekerja agar selalu mendapat dukungan dari pemilih. ${ }^{8}$

\footnotetext{
${ }^{7}$ ibid.

8 ibid.[21].
} 
Kelima, penyelenggaran Pemilihan Umum serentak dengan menggunakan model kelima diawali dengan penyelenggaraan Pemilihan Umum serentak tingkat nasional yang melakukan pemilihan terhadap presiden, DPR, serta DPD terlebih dahulu yang kemudian dilanjutkan dengan penyelenggaran Pemilihan Umum lokal dan regional serentak pada tingkatan provinsi (model concurrent national election with flexible concurrent local elections at provincial levels). Dalam model ini terdapat kelemahan yaitu tidak akan adanya nilai tambah dalam penguatan pemerintahan nasional dengan pemerintahan daerah dari hasil penyelenggaraan Pemilihan Umum karena siklus Pemilihan Umum lokal masih menyesuaikan jadwal provinsi masing-masing yang membuat intensitas Pemilihan Umum lokal tinggi. ${ }^{9}$ Akan tetapi juga terdapat kelebihan dengan digunakannya sistem ini yaitu dapat lebih menyederhanakan sistem pemilihan. ${ }^{10}$

Keenam, dalam penyelenggaraan Pemilihan Umum serentak model ini diawali dengan penyelenggaraan Pemilihan Umum serentak untuk memilih Presiden dan wakil presiden serta untuk memilih anggota DPR, DPD dan DPRD kemudian setelah adanya jeda waktu tertentu diikuti dengan penyelenggaraan Pemilihan Umum serentak eksekutif yang dilakukan berbarengan dalam satu provinsi. Untuk Pemilihan Umum eksekutif yang dilakukan secara berbarengan satu provinsi, Pemilihan Umum serentak untuk tingkatan lokal hanya untuk melakukan pemilihan terhadap gubernur, bupati, dan atau walikota dengan berbarengan pada suatu provinsi yang kemudian jadwalnya mengikuti siklus penyelenggaran Pemilihan Umum lokal dimasing-masing provinsi dengan adanya kesepakatan yang telah disepakati. ${ }^{11}$ Model penyelenggaran Pemilihan Umum serentak yang keenam disebut juga dengan Pemilihan Umum serentak lima kotak (Presiden, DPR, DPD, DPRD Provinsi, dan DPRD Kabupaten/Kota) yang merupakan model Pemilihan Umum yang telah digunakan pada Pemilihan Umum serentak bulan april yang lalu. ${ }^{12}$

\footnotetext{
9 ibid.[26].

${ }^{10}$ ibid. [22].

${ }^{11}$ ibid.

${ }^{12}$ ibid. [26].
} 
Penggunaan Pemilihan Umum serentak model ini adalah dapat terjadinya suatu kesenjangan antara Pemilihan Umum eksekutif serta Pemilihan Umum legislatif lokal yang berkaitan dengan waktu pemilihan. ${ }^{13}$ Kelebihan yang didapatkan dari penggunaan sistem Pemilihan Umum serentak ini tidak jauh berbeda dengan yang lain yaitu akan membuat sisem pemilihan menjadi lebih sederhana.

Berdasarkan keenam model Pemilihan Umum yang telah dijabarkan, penyelenggaraan Pemilihan Umum serentak dengan model pertama dan kedua akan menjadi jawaban dari tujuan Pemilihan Umum serentak untuk menghemat biaya anggaran, akan tetapi pelaksanaan Pemilihan Umum serentak akan menjadi lebih rumit, lalu terjadi ketidaktentuan dalam konfigurasi politik, dan dapat juga tidak memunculkan political blocking, serta dapat menumbuhkan politik transaksional oleh karena dalam mendapatkan kemenangan dalam Pemilihan Umum membutuhkan dukungan elektoral. Sehingga penyelenggaraan Pemilihan Umum serentak dengan model ketiga, keempat dan kelima akan menghasilkan sistem pemilihan lebih sederhana. ${ }^{14}$ Dihasilkanya sistem yang lebih sederhana dengan model Pemilihan Umum serentak ketiga, keempat dan kelima karena penyelenggaran Pemilihan Umum anggota DPR serta Pemilihan Umum presiden secara berbarengan maka akan cenderung menghasilkan dua blok besar koalisi partai politik karena keduanya sama-sama mencalonkan pasangan calon presiden dan wakil presiden oleh karena kesempatan untuk cenderung kearah dua putaran atau hanya ada dua kandidat utama sangatlah besar. ${ }^{15}$

\section{Model Pemilihan Umum Alternatif Pada Pelaksanaan Pemilihan Umum Serentak Nasional}

Pemilihan Umum serentak yang telah diselenggarakan pada beberapa bulan yang lalu telah menggunakan model keenam Pemilihan Umum serentak atau yang dikenal dengan Pemilihan Umum serentak lima kotak. Pada Pemilihan Umum lima

\footnotetext{
13 ibid.

14 ibid.[22]

15 ibid.[23].
} 
kotak tersebut, penyelenggaraan Pemilihan Umum serentak dilaksanakan untuk memilih Presiden, DPR, DPD, DPRD Provinsi, DPRD Kabupaten/Kota.

Pelaksanaan Pemilihan Umum serentak lima kotak tersebut merupakan hasil dari Putusan Mahkamah Konstitusi Nomor 14/PUU-XI/2013 yang merupakan hasil dari dikabulkannya permohonan dari pemohon yaitu Effendi Gazali terkait adanya beberapa pasal dalam Undang-Undang yang inskonstitusional dengan Undang-Undang Dasar, dengan adanya keputusan tersebut maka lahirlah pelaksanaan Pemilihan Umum serentak yang telah selesai diselenggarakan pada bulan april yang lalu dan pelaksanaan Pemilihan Umum serentak pada Pemilihan Umum selanjutnya. ${ }^{16}$

Akan tetapi dalam Putusan Mahkamah Konstitusi Nomor 14/PUU-XI/2013 tidak memberikan definisi yang jelas terkait dengan pelaksanaan Pemilihan Umum serentak yang berarti memisahkan antara Pemilihan Umum di tingkat nasional dengan Pemilihan Umum di tingkat lokal, jadi terkait pengertian tentang Pemilihan Umum serentak diserahkan kepada para pembentuk undang-undang. Selain tidak diberi pengertian yang jelas terkait apa yang dimaksud dengan Pemilihan Umum serentak, Susi Dwi Harijanti yang merupakan guru besar hukum tata negara universitas padjajaran juga ikut memberikan komentar kepada Putusan Mahkamah Konstutusi Nomor 14/PUU-XI/2013. Menurutnya putusan tersebut tidak memberikan penjelasan serta petunjuk terkait Pemilihan Umum serentak dan jika dibandingkan dengan putusan terdahulu yaitu Putusan Mahkamah Konstitusi Nomor 51-52-59/PUU-VI/2008 terjadi inkonsistensi antara dua putusan tersebut padahal ketentuan yang diujikan adalah sama yaitu terkait aturan Pemilihan Umum calon anggota legislatif dengan Pemilihan Umum Presiden dan Wakil Presiden. Dalam Putusan Mahkamah Konstitusi Nomor 51-52-59/PUU-VI/2008 memberikan ketentuan terkait pelaksanaan Pemilihan Umum Presiden dan Wakil Presiden serta Pemilihan Umum legislatif yang diselenggarakan secara terpisah

\footnotetext{
${ }^{16}$ Wahyu Widodo, 'Pelaksanaan Pemilihan Umum Seretak Ditinjau Dari Prespektif Politik Dan Hukum’ (2018) 1 Jurnal Meta-Yuridis.[23].
} 
tetaplah konstitusional. ${ }^{17}$ Sehingga pelaksanaan Pemilihan Umum serentak 2019 menggunakan model yang ditentukan oleh para pembentuk undang-undang yaitu menggunakan model lima kotak atau surat yang merupakan suatu original intent dari para pelaku perumus undang-undang, akan tetapi dalam penyelenggaraanya pada Pemilihan Umum serentak 2019 tidak memberikan hasil yang sesuai dengan tujuan diadakannya Pemilihan Umum serentak dan mendapatkan banyak persoalan yang berkaitan dengan tata kelola dalam pelaksanaan Pemilihan Umum serentak tersebut. Salah satu dari persoalan yang mendapat perhatian khusus adalah banyaknya korban jiwa dari penyelenggaraan Pemilihan Umum tersebut akibat dari kelelahan saat menyelenggarakan Pemilihan Umum serentak, yang banyak menjadi korban jiwa adalah para petugas penyelenggara Pemilihan Umum terutama adalah petugas KPPS. ${ }^{18}$

Dalam model pelaksanaan Pemilihan Umum serentak, Bivitri Susanti seorang dosen hukum tata negara STIH Jentera memberikan pendapatnya bahwa pelaksanaan Pemilihan Umum serentak masih relevan untuk dilaksanakan pada Pemilihan Umum yang akan mendatang dengan menggunakan model pemisahan antara Pemilihan Umum di tingkat nasional dan di tingkat lokal, jadi pelaksanaan model Pemilihan Umum serentak adalah Pemilihan Umum di tingkat lokal dilaksanakan terlebih dahulu baru sesudahnya adalah pelaksanaan Pemilihan Umum di tingkat nasional. Pendapat tersebut berbeda dengan Syamsuddin Haris, dkk. Menurut Syamsuddin Haris,dkk model Pemilihan Umum yang paling ideal dan dapat dilaksanakan untuk Pemilihan Umum yang akan datang adalah model Pemilihan Umum ketiga yang melakukan pemisahan antara penyelenggaraan Pemilihan Umum lokal untuk memilih anggota DPRD provinsi dan DPRD kabupaten/kota serta untuk memilih kepala-kepala daerah baik provinsi maupun

17 Aida Martillah, 'Membedah Putusan MK Soal Pemilihan Umum Serentak', Hukum Online, 2019, https://www.hukumonline.com/berita/baca/lt5ce3aaff452a7/membedah-putusan-mksoal-Pemilihan Umum-serentak/, diakses pada 30 November 2019.

${ }^{18}$ Ady Thea DA, 'Dilema Sistem Pemilihan Umum Serentak', Hukum Online, 2019, https:// www.hukumonline.com/berita/baca/lt5cdef3179f31b/dilema-sistem-Pemilihan Umum-serentak/, diakses pada tanggal 23 November 2019. 
kabupaten/kota dengan Pemilihan Umum nasional untuk memilih presiden serta wakil presiden dan untuk memilih DPR dengan DPD yang diberikan jarak 2,5 tahun dengan didahului oleh Pemilihan Umum nasional terlebih dahulu. Dijelaskan juga dalam kajian implikasi penerapan sistem baru yang terdapat dalam naskah akademik Undang-Undang Nomor 7 Tahun 2017 tentang Pemilihan Umum yang menyatakan bahwa penyelenggaran Pemilihan Umum serentak yang memisahkan tingkat nasional serta tingkat lokal dengan memberi jarak waktu 24-30 bulan akan banyak mendapatkan konsekuensi politik yang positif bagi konsolidasi demokrasi Indonesia. Oleh karena itu akan terdapat banyak kelebihan yang akan dirasakan oleh para pihak dalam menggunakan model Pemilihan Umum serentak ketiga yang memisahkan Pemilihan Umum nasional dengan Pemilihan Umum lokal antara lain yang dirasakan oleh para pemilih dimana mereka akan memiliki kesempatan untuk mencari informasi terhadap kandidat yang akan mereka pilih dalam Pemilihan Umum dengan sebanyak mungkin sehingga dalam menentukan pilihannya para pemilih akan lebih bersikap rasional. ${ }^{19}$

Kelebihan yang akan dirasakan pemerintah adalah dalam penguatan sistem presidensialisme, pemisahan Pemilihan Umum lokal serentak dengan Pemilihan Umum nasional serentak adalah untuk menigkatkan sistem presidensialisme karena presiden yang terpilih dalam Pemilihan Umum nasional serentak akan memberikan pengaruh terhadap hasil Pemilihan Umum legislatif karena pasangan calon presiden dan wakil presiden yang memperoleh kemenangan akan memberikan pengaruh terhadap penguasaan kursi legislatif. Sehingga legislatif yang terpilih akan memberikan dukungan yang besar terhadap presiden yang terpilih dan hal tersebut akan memberikan otoritas yang cukup kepada pemerintah untuk membuat rumusan, mengambil kebijakan serta menerapkan kebijakan publik tersebut tanpa adanya tekanan dari pihak parlemen..$^{20}$ Ditambah juga pemerintahan yang terbentuk akan lebih meningkat efektivitasnya karena Pemilihan Umum presiden dan Pemilihan Umum legislatif yang dilaksanakan secara serentak akan juga lebih stabil sebagai

\footnotetext{
19 Syamsuddin Haris, Op.Cit.[34].

${ }^{20}$ ibid.
} 
akibat dari terjadinya coattail effect. ${ }^{21}$ Coattail Effect merupakan sebuah sebutan yang menunjukan suatu tindakan yang mengakibatkan timbulnya pengaruh terhadap tindakan lain serta diartikan juga dalam terjemahan bebas sebagai dampak kibasan buntut jas. Artinya adalah elektabilitas suara pada suatu partai politik pengusung akan dipengaruhi oleh calon pemimpin yang diusung dari partai politik tersebut. ${ }^{22}$ Contoh coattail effect dapat dilihat dari kemenangan PDIP dalam pemilihan anggota legislatif secara berturut-turut yaitu pada Pemilihan Legislatif 2014 serta Pemilihan Legislatif 2019, menurut pengamat politik Arif Sutanto yang berasal dari Universitas Paramadina menyatakan bahwa PDIP ikut memperoleh keutungan dari coat-tail effect dengan melakukan pencalonan terhadap Joko Widodo sebagai calon presiden. Oleh karena PDIP merupakan salah satu partai yang mengusung Joko Widodo dan merupakan partai dimana Joko Widodo bernaung. ${ }^{23}$ Dengan adanya coattail effect akan menciptakan koordinasi yang baik dan sinergis dalam suatu pemerintahan antara eksekutif dan legislatifnya karena eksekutif dan legislatif yang menjabat tersebut memilih persamaan dalam partai pengusung. ${ }^{24}$ Kelebihan selanjutnya adalah kebijakan pemerintahan nasional akan dapat berjalan dengan baik pada tingkat daerah serta garis hierarki dan harmonisasi dan sinergi pemeritahan dari pusat, provinsi serta kabupaten/kota karena kecenderungan koalisi partai poltik untuk mempertahankan koalisinya untuk kembali berkompetisi pada pelaksanaan Pemilihan Umum lokal jika pasangan calon presidennya terpilih dalam Pemilihan Umum nasional. ${ }^{25}$

Kelebihan yang dirasakan oleh pemerintahan lokal adalah berkaitan dengan isu-isu lokal yang akan lebih terangkat ke dalam tingkat nasional dan juga membuka semakin besarnya peluang elite partai lokal yang berhasil dalam kepemimpinannya

\footnotetext{
${ }^{21}$ Ni'matul Huda, Desain Pemilihan Umum Serentak 2019 Dalam Hegemoni Partai Politik, (Pustaka Belajar 2019).[15].

${ }^{22}$ Nur Rohim Yunus, 'Coattail Effect Pada Ajang Pemilihan Umum Presiden 2019' (2018) 2, Jurnal Adalah Buletin Hukum dan Keadilan.[80].

23 'Pecah Rekor PDIP Dan Berkah Efek Jokowi Di Pemilihan Umum 2019', CNN Indonesia, 2019, https://www.cnnindonesia.com/nasional/20190521143515-32-396903/pecah-rekor-pdip-danberkah-efek-jokowi-di-Pemilihan Umum-2019, diakses pada tanggal 28 November 2019.

${ }^{24}$ Nur Rohim Yunus, Loc.Cit.

25 Syamsuddin Haris, Op.Cit.[34-35].
} 
untuk dapat bersaing menjadi elite politik dalam tingkat nasional. ${ }^{26}$ Dari sisi politik, rekruitmen para calon anggota legislatif akan lebih baik karena para pengurus parpol lebih berkonsentrasi dalam melakukannya, selain itu calon yang tidak terpilih dalam pemilihan dapat mengajukan kembali dalam penyelenggaraan pemilihan daerah sehingga calon yang tersedia akan lebih banyak. Dengan adanya kondisi tersebut maka dapat meminimalkan fenomena kandidat "jual putus" adalah suatu fenomena dimana partai politik melakukan penjualan berkas pencalonan kepada orang-orang yang memiliki kemampuan untuk melakukan pembayaran dengan biaya yang mahal. ${ }^{27}$ Serta lebih dapat menegakan disiplin partai dalam pelaksanaan Pemilihan Umum serentak.. Konflik internal partai juga akan lebih berkurang karena dalam kurun lima tahun hanya akan terjadi dua momentum, yang mengakibatkan konflik yang biasanya terjadi dalam pemilihan kepala daerah yang dilaksanakan sepanjang tahun akan berkurang dengan dua moementum pelaksanaan Pemilihan Umum yaitu Pemilihan Umum serentak lokal dan Pemilihan Umum serentak nasional, waktu yang cukup banyak tersebut dapat digunakan partai politik untuk lebih memperhatikan anggota serta konstituennya. ${ }^{28}$ Para partai politik juga akan lebih kompak dalam bekerja tidak hanya pada saat penyelenggaraan Pemilihan Umum, akan tetapi setelah diselenggarakannya Pemilihan Umum partai politik juga akan tetap solid dalam bekerja dan bersungguh-sungguh untuk melakukan kerjasama agar dapat mendapatkan kemenangan dalam Pemilihan Umum, situasi ini menunjukkan bahwasannya jika kepala daerah dan partai politik tidak bekerja dengan baik dan sesuai dengan rakyat dalam masa jabatannya akan mendapatkan hukuman dari pemilih ketika Pemilihan Umum nasional. ${ }^{29}$

Pemisahan Pemilihan Umum serentak nasional dengan Pemilihan Umum serentak lokal juga akan cenderung mengarahkan kepada sistem multipartai yang sederhana (moderat). ${ }^{30}$ Berdasarkan kelebihan-kelebihan yang dimiliki oleh

\footnotetext{
26 Ni'matul Huda, Op.Cit.[16].

7 Syamsuddin Haris, Op.Cit.[33].

ibid.[35].

ibid.[36].

Ni'matul Huda, Op.Cit.[16].
} 
model Pemilihan Umum serentak ketiga yang memisahkan Pemilihan Umum nasional dengan Pemilihan Umum lokal dengan memberi jeda waktu, maka model Pemilihan Umum serentak yang ketiga sangatlah tepat digunakan oleh Indonesia untuk pelaksanaan Pemilihan Umum yang akan diselenggarakan pada waktu yang akan datang.

\section{Konstitusionalitas Penyelenggaraan Pemilihan Umum Nasional Serentak Terpisah Dari Pemilihan Umum Lokal Serentak}

Putusan Mahkamah Konstitusi Nomor 14/PUU-XI/2013 tidak membahas secara jelas terkait dengan pemisahan Pemilihan Umum lokal dengan Pemilihan Umum nasional, akan tetapi dalam pertimbangannya yang menyatakan bahwa pasal 22E ayat (2) UUD NRI 1945 harus dalam satu tarikan nafas saat membacanya menimbulkan suatu ketentuan bahwa pelaksanaan pemilihan legislatif yaitu untuk memilih DPR, DPD dan DPRD dengan Pemilihan Umum Presiden dan Wakil Presiden merupakan suatu kesatuan yang berarti pelaksanaannya tidak dapat dipisahkan. ${ }^{31}$ Penafsiran yang tepat untuk menafsirkan pasal 22E ayat (2) UUD NRI 1945 adalah penafsiran yang menggunakan penekanan pada arti kata atau istilah (taalkaundige interpretasi) yang terdapat di dalam pasal 22E ayat (2) UUD NRI 1945, jadi seorang hakim memiliki kewajiban untuk mencari arti kata dalam undang-undang tersebut dengan cara melihat kamus bahasa atau dengan bantuan keterangan ahli bahasa dan jika hal tersebut dinilai belum cukup maka hakim diberikan kewajiban untuk mempelajari kata tersebut dalam susunan kata kalimat dan yang berhubungan dengan peraturan-peraturan lainnya. ${ }^{32}$ Jika dilihat dalam Pasal 22E ayat (2) UUD NRI 1945 frasa “dan Dewan Perwakilan Rakyat Daerah" terletak di akhir ayat yang seharusnya terletak di tengah atau terletak didepan sebelum frasa "presiden dan wakil presiden". Kondisi tersebut menghasilkan dua kemungkinan, yaitu: tujuan diletakannya frasa tersebut di penghujung ayat adalah menyatakan bahwa pemilihan anggota DPRD tidaklah satu nafas dengan Pemilihan

\footnotetext{
31 ibid. [55].

32 Jimly Asshiddiqie, Pengantar Ilmu Hukum Tata Negara (RajaGrafindo Persada 2010), [225].
} 
Umum untuk memilih anggota DPR serta anggota DPD karena jika memang para pengubah Undang Undang Dasar Negara Republik Indonesia Tahun 1945 memiliki tujuan untuk membuat Pemilihan Umum anggota DPRD senafas dengan Pemilihan Umum DPR serta DPD maka letaknya tidak akan dilakukan pemisahan atau diberikan batasan oleh norma yang lain tidak sejenis. Di dalam pasal tersebut terlihat bahwa terdapat pemisahan antara norma Pemilihan Umum anggota DPR dan DPD dengan norma Pemilihan Umum anggota DPRD dan kemungkinan yang kedua adalah ketentuan dalam pasal 22E ayat (2) UUD NRI 1945 menunjukan suatu urutan antara Pemilihan Umum nasional dengan Pemilihan Umum lokal, karena terlihat bahwa letak Pemilihan Umum untuk memilih DPR, DPD serta presiden dan wakil presiden berurutan tata letaknya. Namun berbeda dengan tata letak Pemilihan Umum DPRD yang tidak diletakkan berurutan seteleh frasa Pemilihan Umum DPR atau DPD dan peletakan Pemilihan Umum DPRD malah terletak diujung ayat. Berdasarkan penafsiran tersebut, membuat masih terbuka lebar kesempatan untuk memisahkan pelaksanaan Pemilihan Umum nasional dengan Pemilihan Umum lokal dan jika dikaitkan dengan penafisran menurut makna tekstual yang dilakukan oleh mahkamah konstitusi terhadap ketentuan yang terdapat dalam pasal 22E ayat (2) UUD NRI 1945, pada intinya dalam melakukan tafsiran sistematis terhadap pasal 22E dan pasal 6A ayat (2) UUD NRI 1945 mahkamah konstitusi juga harus melakukan penafsiran tekstual juga. ${ }^{33}$ Selanjutnya adalah terkait pelaksanaan penggabungan Pemilihan Umum lokal serentak yang memiliki dua ketentuan yang berbeda yaitu pemilihan anggota DPRD diatur dengan pasal 22E ayat (2) UUD NRI 1945 sedangkan pemilihan kepala daerah diatur dengan ketentuan pasal 18 ayat (4) UUD NRI 1945 yang berarti Pemilihan Umum DPRD dengan Pemilihan Umum kepala daerah terletak dalam dua rezim yang berbeda. Akan tetapi, jika dicermati lagi dalam pasal 18 ayat (3) UUD NRI 1945 terdapat ketentuan terkait Pemilihan Umum anggota DPRD dalam ketentuan pasal 18 ayat (3) UUD NRI 1945 menyatakan: ${ }^{4}$ "Pemerintahan daerah provinsi, daerah kabupaten, dan kota

\footnotetext{
33 Syamsuddin Haris, Op.Cit.[56].

${ }^{34}$ Pasal 18 (3) Undang-Undang Dasar Negara Republik Indonesia Tahun 1945.
} 
memiliki Dewan Perwakilan Rakyat Daerah yang anggota-anggotanya dipilih melalui pemilihan umum".

Untuk ketentuan terkait pemilihan kepala daerah terletak dalam pasal 18 ayat (4) UUD NRI 1945. Apabila memahami ketentuan pasal 18 UUD NRI 1945 dalam satu kesatuan sistem norma peraturan perundang-undangan maka harus dapat dipahami juga bahwa ketentuan yang diatur dalam Pasal 18 ayat (3) UUD NRI 1945 dengan Pasal 18 ayat (4) UUD NRI 1945 merupakan satu kesatuan yang tidak dapat terpisahkan. ${ }^{35}$ Kepala daerah dengan DPRD memiliki sejumlah persamaan yaitu terletak dalam rezim yang sama yaitu rezim pemerintahan daerah, memiliki ruang lingkup daerah pemilihan yang sama, dan juga para pemilihnya sama, serta memiliki kesetaraan dalam tingkat legitimasi. Sehingga penggabungan pemilihan kepala daerah dengan pemilihan anggota DPRD menjadi Pemilihan Umum lokal serentak sangat dapat dilakukan walaupun dalam Putusan Mahkamah Konstitusi Nomor 97/PUU-XI/2013 dinyatakan secara eksplisit sebagai berikut:

"Walaupun terdapat kemungkinan pemilihan kepala daerah diatur dengan undang-undang tersendiri, namun pemilihan kepala daerah tidaklah termasuk kedalam rezim pemilihan umum yang terdapat dalam pasal 22E UUD NRI $1945^{\prime \prime}$

Jika dilakukan perbandingan dengan pertimbangan hukum mahkamah konstitusi yang terdapat dalam Putusan Mahkamah Konstitsui Nomor 072-073/PUUII/2004, yang didalam putusan tersebut tidak melakukan pengeluaran pemilihan kepala daerah dari rezim Pemilihan Umum namun hanya memberikan penilaian jika Pemilihan Kepala Daerah merupakan suatu perluasan dari rezim Pemilihan Umum yang terdapat dalam ketentuan pasal 22E UUD NRI 1945 maka pembentuk undang-undang yang akan memberikan ketentuannya. Dengan perbedaan dalam kedua putusan terkait rezim Pemilihan Kepala Daerah menunjukkan bahwa terdapat inkonsistensi mahkamah konstitusi dalam menafsirkan status dari rezim hukum Pemilihan Kepala Daerah. Namun pada intinya terdapatnya sebuah perbedaan antara status rezim Pemilihan Umum DPRD dengan Pemilihan Kepala

35 ibid.[58]. 
Daerah bukan merupakan suatu halangan untuk melakukan penggabungan kedua pemilihan tersebut menjadi Pemilihan Umum lokal yang akan dilakukan secara serentak, karena bentuk penggabungan tersebut merupakan suatu penyatuan proses pelaksanaan. Sebab untuk Pemilihan Umum anggota DPRD dan Pemilihan Kepala Daerah dalam proses pelaksanaannya, tetap dilaksanakan oleh KPU berikut jajarannya di masing-masing daerah. Sehingga, jika proses penggabungan tersebut diatur dengan sebuah undang undang maka tidak terdapat satu alasan pun yang dapat mempersoalkan konstitusionalitasnya. ${ }^{36}$

\section{Kesimpulan}

Undang-Undang Nomor 7 Tahun 2017 tentang Pemilihan Umum yang mengatur ketentuan tentang Pemilihan Umum serentak yang merupakan pelaksanaan dari Putusan Mahkamah Konstitusi Nomor 14/PUU-XI/2013 perlu dilakukan revisi karena pelaksanaan Pemilihan Umum serentak dengan menggunakan lima kotak untuk memilih presiden dan wakil presiden, DPR, DPD serta DPRD provinsi dan DPRD kabupaten/kota yang telah diselenggarakan dalam Pemilihan Umum serentak 2019 memiliki banyak kelemahan terhadap banyak pihak serta dianggap kurang pas bagi pelaksanaan Pemilihan Umum serentak untuk selanjutnya. Revisi tersebut dilakukan untuk mengganti model Pemilihan Umum serentak yang terdapat dalam Undang-Undang Nomor 7 Tahun 2017 tentang Pemilihan Umum menjadi Pemilihan Umum serentak yang terdiri dari dua rezim Pemilihan Umum serentak. Model Pemilihan Umum alternatif yang paling ideal dan realistis untuk dilaksanakan di Indonesia kedepannya adalah model Pemilihan Umum serentak yang membagi Pemilihan Umum serentak menjadi dua rezim, yaitu Pertama Pemilihan Umum serentak nasional untuk memilih Presiden, DPR, dan DPD yang diselenggarakan secara serentak; dan Kedua Pemilihan Umum serentak lokal untuk memilih Gubernur, Bupati/Walikota, DPRD Provinsi, dan DPRD Kabupaten/Kota. Pelaksanaan Pemilihan Umum serentak nasional dan Pemilihan Umum serentak

36 ibid.[60-61]. 
lokal dilaksanakan diwaktu yang berbeda. Sistem pelaksanaan Pemilihan Umum serentak nasional dilaksanakan terlebih dahulu selanjutnya dengan jeda waktu dua atau tiga tahun kemudian dilanjutkan dengan penyelenggaraan Pemilihan Umum serentak lokal.. Selain itu, disarankan bagi penulis selanjutnya untuk melakukan kajian terhadap Undang-Undang Pemilihan Kepala Daerah agar terdapat keselarasan undang-undang dalam pelaksanaan Pemilihan Umum.

\section{Daftar Pustaka}

\section{Buku}

Jimly Asshiddiqie, Pengantar Ilmu Hukum Tata Negara (RajaGrafindo Persada 2010).

Ni'matul Huda, Desain Pemilihan Umum Serentak 2019 Dalam Hegemoni Partai Politik (Pustaka Belajar 2019).

Syamsuddin Haris, Pemilihan Umum Nasional Serentak 2019 (Pustaka Belajar 2016).

\section{Jurnal}

Nur Rohim Yunus, 'Coattail Effect Pada Ajang Pemilihan Umum Presiden 2019', (2018), 2 Jurnal Adalah Buletin Hukum dan Keadilan.

Wahyu Widodo, 'Pelaksanaan Pemilihan Umum Seretak Ditinjau Dari Prespektif Politik Dan Hukum' (2018), 1 Jurnal Meta-Yuridis.

\section{Laman}

Ady Thea DA, 'Dilema Sistem Pemilihan Umum Serentak', Hukum Online, 2019, https://www.hukumonline.com/berita/baca/lt5cdef3179f31b/dilema-sistemPemilihan Umum-serentak/, diakses pada tanggal 23 November 2019

Aida Martillah, 'Membedah Putusan MK Soal Pemilihan Umum Serentak', Hukum Online,2019, https://www.hukumonline.com/berita/baca/lt5ce3aaff452a7/ membedah-putusan-mk-soal-Pemilihan Umum-serentak/, diakses pada 30 November 2019.

Khadijah Nur Azizah, 'Kelelahan Dan Kaitannya Dengan Kematian Mendadak Petugas KPPS', Detik News, 2019, https://health.detik.com/beritadetikhealth/d-4548216/kelelahan-dan-kaitannya-dengan-kematian- 
mendadak-petugas-kpps. diakses pada tanggal 13 Agustus 2019.

Sandro Gatra, 'Data Kemenkes: 527 Petugas KPPS Meninggal, 11.239 Orang Sakit', Kompas News, 2019, https://nasional.kompas.com/ $\mathrm{read} / 2019 / 05 / 16 / 17073701 /$ data-kemenkes-527-petugas-kpps-meninggal11239-orang-sakit?page=all, diakses pada tanggal 22 Okotober 2019.

'Pecah Rekor PDIP Dan Berkah Efek Jokowi Di Pemilihan Umum 2019', CNN Indonesia, 2019, https://www.cnnindonesia.com/ nasional/20190521143515-32-396903/pecah-rekor-pdip-dan-berkah-efekjokowi-di-Pemilihan Umum-2019, diakses pada tanggal 28 November 2019.

\section{Perundang-undangan}

Undang-Undang Dasar Negara Republik Indonesia Tahun 1945 
Octara Steni: Model Pemilihan Umum...

--halaman ini sengaja dibiarkan kosong-- 